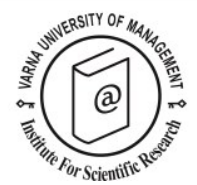

\title{
An Importance-Performance analysis of tourist satisfaction at destination level: evidence from Campania (Italy)
}

\author{
Alessandro De Nisco ${ }^{1 *}$, Angelo Riviezzo ${ }^{2}$ and Maria Rosaria Napolitano ${ }^{3}$
}

Received: 03/01/2014 Accepted: 29/06/2014

\footnotetext{
${ }^{1}$ PhD, Assistant Professor of Marketing, Department DEMM, University of Sannio, via Delle Puglie $82-82100$ Benevento (Italy).Ph: (+39) 0824 305754; Fax: (+39) 0824 305777; Mail: denisco@unisannio.it

${ }^{2} \mathrm{PhD}$, Assistant Professor of Business Strategy and Business Planning, Department DEMM, University of Sannio.

${ }^{3}$ Full Professor of Marketing and Business Strategy, Department DEMM, University of Sannio.

* Corresponding author
}

\begin{abstract}
In this paper we use the Importance-Performance Analysis (IPA) scheme in order to analyze tourist satisfaction in a holiday destination. Arising from service and tourism marketing literatures, the study selects a set of components of the tourism experience that are willing to affect satisfaction. The IPA scheme is applied though a survey conducted on a sample of 1.936 national and international tourists intercepted at the end of their journey in the region of Campania (Italy). Although the IPA scheme has been used in past research in the tourism field, only a few studies have applied this tool from a destination perspective. Based on the results, the paper concludes with discussion of implications for both practitioners and academics.
\end{abstract}

(c) 2015 Varna University of Management. All rights reserved

Keywords: Importance-Performance Analysis (IPA), tourist satisfaction, destination management, Italy.

Citation: De Nisco, A., A. Riviezzo and M.R. Napolitano (2015) An Importance-Performance analysis of tourist satisfaction at destination level: evidence from Campania (Italy). European Journal of Tourism Research 10, pp. 64-75

\section{Introduction}

There is growing evidence that customer satisfaction is a driving force behind firm's business competitiveness and performance (Parasuraman et al., 1985, 1988; Zeithaml et al., 1996). This is also true in the case of tourism, where there is a wide application of concepts, models and tools aimed to evaluate customer satisfaction. It is recognized that in order to identify the strengths and the weaknesses of a tourist destination and to improve its competitiveness, it is essential to "listen to the customer". Satisfaction is commonly considered as the best indicator of the state of health of tourism, since it is directly connected to expected loyalty (Del Bosque and 
San Martin, 2008; De Nisco et al., 2012) and, therefore, is a source of competitive advantage.

This paper adopts a service marketing perspective for the measurement of tourist satisfaction and it proposes the ImportancePerformance Analysis (IPA) as a tool for evaluating satisfaction towards a holiday destination. Although the use of IPA as an instrument for the measurement of quality perceptions is well documented in both marketing (Ennew et al., 1993; Slack, 1994; Matzler et al., 2003) and tourism literatures (Duke and Persia, 1996; Zhang and Chow, 2008; Wilkins, 2010; Söresson and von Friedrichs, 2013), it seems that there still remain some gap that call for further research in this field. Namely, most of the studies that have employed the IPA scheme in the tourism sector focus on specific tourism services like accommodation, transportation, tours and attractions, while research adopting a "destination" perspective is still scarce (Edward and George, 2008). This paper aims to fill in this gap by using the IPA scheme as a valuable and "demand-based" tool to ensure the continuous, dynamic and multi-perspective process of "review and validation" of tourism destination management practices.

From a structural standpoint the paper is organized as follows: in the next paragraph it is reviewed the academic literature on tourist satisfaction. The following paragraph provides a description of the IPA scheme and of its use in the tourism field. Then the IPA scheme is employed to assess satisfaction of a sample of national and international tourists intercepted in the region of Campania, one of the most attractive Italian tourism destinations. Finally, the last paragraph discusses the contribution of the study to the tourism marketing field and the related managerial implications.

\section{Assessing Tourist Satisfaction: emerging issues from literature}

Over the past decades, a growing academic interest was focused on tourist satisfaction (Ryan 1995; Oh and Parks 1997; Pizam and Ellis 1999; Bowen and Clarke, 2002; Yüksel and Yüksel 2001; Casarin and Andreani, 2002; Fuchs and Weiermair, 2003; Geng-Qing Chi and Qu, 2008; Del Bosque and San Martin, 2008; Gursoy et al., 2014), underlining the need of considering the peculiarities of the tourism sector in the measurement and management of satisfaction.

Scholars emphasize the need to make a distinction between the overall satisfaction with the tourist destination and the satisfaction related to the specific components/attributes of the destination itself. More than an industry, tourism can be considered as a "system", characterized by high interdependences among related services such as hotels, restaurants, shops, transportation etc. (Middleton and Clarke, 2001; Casarin and Andreani, 2003). Therefore, besides the functional components, many contextual and environmental factors contribute to the perception of the tourism experience, like for example the "social factors" (i.e. the human interactions leading to experiential benefits and responses) and the "physical environment" (i.e. natural attractions, landscape etc.) (Bitner, 1992; Fuchs and Weiermair, 2003). Since tourists can evaluate the single elements separately, the overall satisfaction with the tourism experience can be considered as a function of the satisfaction with the different elements/attributes experienced during the journey (Oliver, 1993; Pizam and Ellis, 1999; Geng-Qing Chi and Qu, 2008). Such assumption is consistent with service marketing literature: according to Oliver (1993) "attribute satisfaction has significant, positive and direct effects on overall satisfaction". As a consequence, evaluating tourist's satisfaction through the focus on a specific components (like, for instance, the accommodation) may lead to a "paradox" (Casarin and Andreani, 2003), since tourists could be satisfied with specific products/services but not with the overall destination experience.

Within the tourism marketing literature different perspectives and methods have been proposed for the assessment of tourist satisfaction. Most of the contributions in this field are based on the expectation-disconfirmation model, which assumes that consumers develop expectations about a product/service before purchasing it and subsequently they compare actual performance with the pre-purchase expectations (Oliver, 1980). If the performance is better/worse than the expectations, the consumer has a positive/negative 
disconfirmation, which leads to a feel of satisfaction/dissatisfaction. According to this model, it can be argued that tourist satisfaction is "the result of a comparison between [tourist] previous images of the destination and what he/she actually sees, feels and achieves at the destination" (Chon, 1989).

However, more recent contributions criticize the use of expectations in the assessment of tourist satisfaction, because of the difficulties in obtaining a realistic measure of tourists' expectations. In this regard, it has been argued that time plays a relevant role in the evaluation of expectations (Casarin and Andreani, 2003), since tourists form their expectations before leaving and when they still are in their own place of origin. Therefore, assessing expectations during the travel experience may lead to a distortion of the data since tourists could not recall perceptions they had before leaving. Similarly, tourists realize their overall satisfaction with the travel experience when they return to their own place of origin, since at that point they can assimilate the social, cultural and psychological inputs of the experience in their daily life and are able to share them with others. It follows that the evaluation of the performance when tourists are still at the destination may lead to unreliable results. The need to assess expectations and performance at different stages of the holiday experience has been discussed in several theoretical contributions (e.g. Pizam and Milman, 1993), but rarely it has been considered in empirical studies.

As noted by Yoon and Uysal (2005), some contributions suggest the adoption of a "norm" or "comparison standard" instead of expectations as reference points for the disconfirmation process (Francken and van Raaij, 1981; Cadotte et al., 1987). For example, tourists could compare the actual holiday destination with other destinations visited in the past; the difference between present and past experiences can be a norm or comparison point to evaluate tourist satisfaction. Other contributions suggest using only the actual perceived performance, avoiding comparative elements (Tse and Wilton, 1988; Fuchs and Weiermair, 2003). According to such method, the actual performance and initial expectations should be considered independently. Following this approach, all the methodological issues related to the assessment of expectations are avoided, but, at the same time, it is impossible to interpret high levels of satisfaction as the result of low expectations or superior quality of the service provider (Fuchs and Weiermair, 2003).

Tourist satisfaction has also been considered as an emotional response derived from a consumption experience. According to this view, satisfaction is conceptualized as an individual's cognitive-affective state arising from both the individual's cognitive judgements and emotions related to the tourist experience (Oliver, 1993). Satisfaction is therefore influenced by cognitive evaluations (such as expectations and disconfirmation) and, furthermore, by positive and negative emotions that contribute independently to satisfaction. Emotions derive from evaluations and determine the individual's overall responses: it follows that "the more positive the disconfirmation of tourist expectations, the more frequent the positive emotions" (Del Bosque and San Martin, 2008) and, as a consequence, the higher will be the expected loyalty or commitment with the destination.

Arising from the above review of the extant literature, it is evident that surveys aimed at assessing tourist satisfaction must face several challenges. Therefore, they are useful and reliable only if meticulously designed and carefully administered. Besides the conceptual constructs and the theoretical model adopted, decisions such as the choice of the interview method, the sample design, the timing and placing are all highly critical issues in tourist satisfaction surveys that may invalidate the results "if improperly chosen and/or managed" (Fuchs and Weiermair, 2003).

\section{The IPA scheme in the tourism field}

The Importance-Performance Analysis (IPA) is a scheme in line with the expectationsperformance approach and its use is well documented in the marketing literature (Ennew et al., 1993; Slack, 1994; Matzler et al., 2003). Although the use of IPA scheme has lost favour in the last few years as consequence of the development of more complex quantitative 
methods (Duke and Mount, 1996), since this approach was proposed by Martilla and James (1977), academic literature is replete of studies providing empirical applications in various settings, such as transportation (e.g. Huang and Hsu, 1996), banks (e.g. Josepph et al., 2005), universities (e.g. Pike, 2004), hospitality (e.g. Janes and Wisnom, 2003), town centre management (e.g. Riviezzo et al., 2009), and tourism (e.g. Duke and Persia, 1996; Fuchs and Weiermair, 2003; Wade and Eagles, 2003; Edward and George, 2008; Zhang and Chow, 2008; Wilkins, 2010; Söresson and von Friedrichs, 2013).

The IPA approach involves assessing different aspects of an organization's features in terms of customers' perceived expectations and performances. In the typical IPA scheme such features are represented in a $2 \times 2$ grid, where each quadrant can be summarized into a specific suggestion for management (Figure 1). In particular, poor performance on extremely important dimensions indicate high priority in intervention for improvement (Concentrate here quadrant); excellent performance on highly important features represent opportunities for gaining or maintaining a competitive advantage
(Keep up the good work quadrant); slightly important features that are excellent in performance imply that resources would be better employed elsewhere (Possible Overkill quadrant); finally, fair performance on slightly important features suggest that it may not be necessary to focus additional effort to these attributes (Low priority quadrant).

In the field of tourism, it has been argued that "for tourist destinations with rather little market research experience, Importance-Performance Analysis in its purest form can be used as a very powerful tool in marketing planning" (Hudson and Shephard, 1998). However, although this scheme has been widely used in the tourism sector, most of research has focused on specific tourism services or attractions. For example, in a study conducted by Zhang and Chow (2008) the IPA scheme was used for the assessment of the performance of Hong Kong's tour guides as perceived by mainland Chinese outbound visitors. Similarly, Duke and Persia (1996) used tourist pre-trip expectations, post-trip satisfactions and importance of each on an IPA grid to consider potential decisions for escorted tours design. Wade and Eagles (2003) used

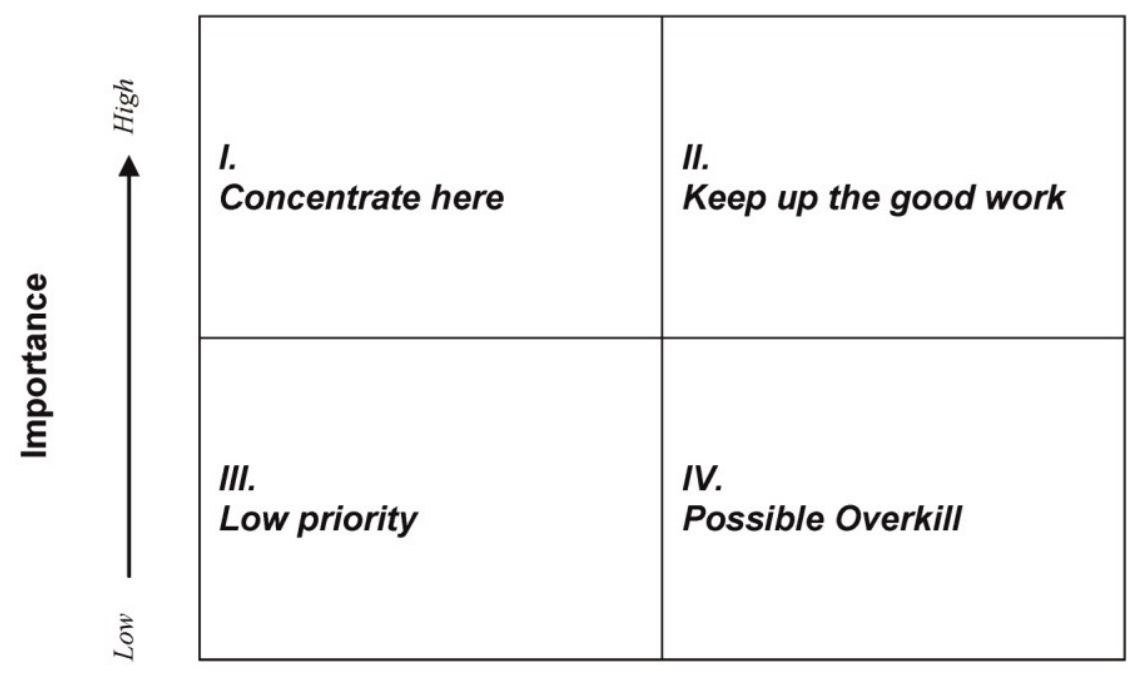

Low

Figure 1. The IPA Scheme

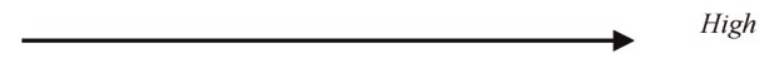

Performance 
the IPA approach to address the market segmentation of Tanzania's National Parks. IPA has also been used to evaluate performances of hotels (Chu and Choi, 2000; Wilkins, 2010) and of tourism events (Deng, 2007; Smith and Costello, 2008). More recently, Söresson and von Friedrichs (2013) used the IPA scheme on a sample of national and international tourists to compare performances of a tourism destination with regard to social and environmental sustainability.

Although such research provide solid support to the use of the IPA method in the tourism field - both for the identification of the main area of intervention (ex-ante evaluation), and as backward-looking instrument aiming to evaluate the impact of the programs and strategies implemented (ex-post evaluation) there seems to be still gaps to be addressed. Namely, while the majority of contributions have focused on specific tourism services/products, only a limited attention has been devoted to the application of the IPA scheme for the evaluation of tourists' satisfaction at a broader tourism destination level (Edward and George, 2008). Therefore, given the service focused approach adopted by this stream of research, most of the studies adopt a limited range of parameters for the assessment of tourists' satisfaction. Many destination elements, like access, transportation, personal safety, information services, are rarely considered as satisfaction attributes, even though they can significantly influence the tourists' holiday experience to an extent.

This study aims to fill in this gap by adopting the IPA approach from a tourism destination perspective. Therefore, tourists' satisfaction is represented on the basis of a large range of both controllable and uncontrollable destination attributes selected on the basis of both service marketing and destination marketing literature. The proposed approach aims to show how the IPA scheme can be used as a reliable and easy to use tool to support both policy makers in the definition of the main area of intervention in order to improve the perceived value of a destination and the tourism companies (like, for instance, hotel and tour operator) in using a destination's strengths in their positioning and advertising strategies at national and international levels.

\section{Using the IPA scheme for the evaluation of tourist satisfaction at destination level: the case of Campania (Italy)}

Campania is a region located in the southern part of Italy and it is considered one of the most attractive Italian tourism destinations. The region offers a wide range of experiences (beaches, historical sites, sanctuaries, natural parks, gastronomy) and includes worldwide renowned attractions like the island of Capri, the Amalfi Coast, Sorrento, the Archaeological Excavations of Pompei and Naples. According to the Italian Statistical Institute (ISTAT) in 2012 the Campania region has attracted 4.3 millions of tourists and it ranked at $7^{\text {th }}$ position among the Italian regions in term of tourists arrivals, with a market share of $11.9 \%$.

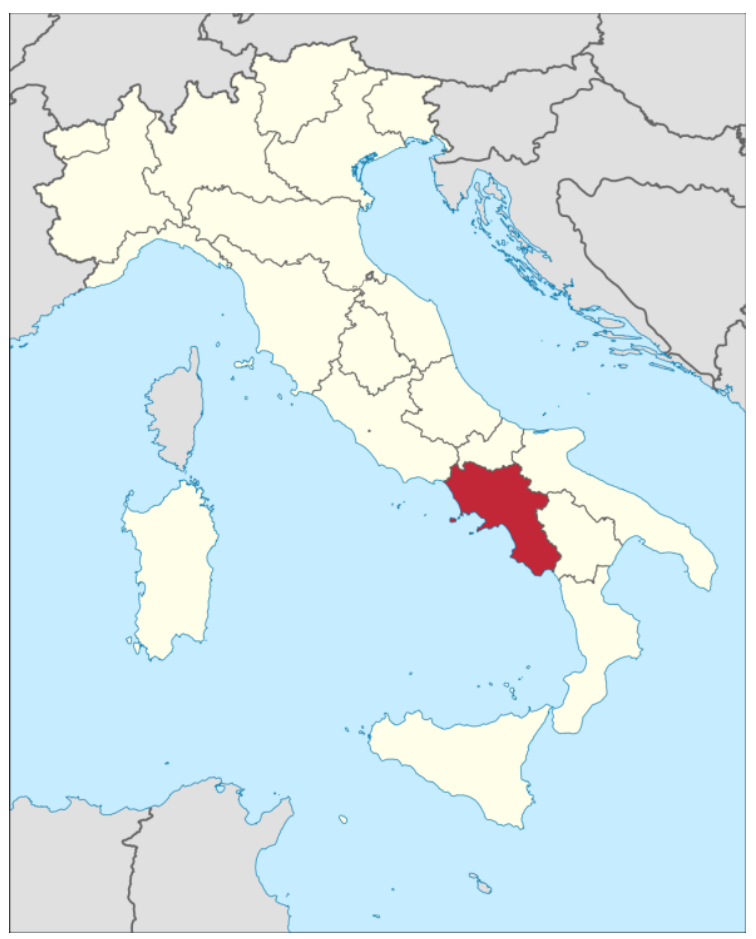

Figure 2.The Campania region

In order to apply the IPA scheme, a research framework was defined to guide the empirical research, including three stages: a) development of the survey instrument; b) 
sampling method and data collection; c) data analysis.

\section{Development of the survey instrument}

In the first stage, a closed-ended questionnaire was designed to provide a broader assessment of tourists' perceptions, and translated in 4 languages (Italian, English, Spanish, Deutsch). The research instrument was divided in four sections, including determinants of the destination choice, travel behaviour, perceived satisfaction and post-visit intentions. Attributes of tourist satisfaction were selected on the basis of previous literature on service marketing and tourism marketing (Chadee and Mattsson, 1996; Tribe and Snaith, 1998; Kozak, 2001; Fuchs and Weiermair, 2003). The satisfaction section enclosed a total of 24 items, grouped in 6 categories:

1) Accommodation and restaurants: this category included the comfort and cleaning of the hotel, the efficiency of contact personnel, the quality and variety of restaurants and the typicality of food and wine proposals;

2) Accessibility: it included the efficiency and adequacy of parking, public transportation, car and walking streets;

3) Tourism services: it evaluated the efficiency of tourism offices, info-point and tourism signals and guided tours;

4) Entertainment facilities: it included the quality of entertainment and shopping facilities;

5) Quality of life: it assessed the perceived level of personal safety, crowdedness and street cleanliness;
6) Heritage and cultural services: this category evaluated the state of maintenance and protection of the historical sites, the quality of routes and historical attractions for tourists, quality of initiatives and events aiming at promoting the historical and artistic patrimony of the destination towards tourists and residents.

The questionnaire was carefully structured and all items were derived and partially adapted from previous studies (Chadee and Mattsson, 1996; Kozak, 2001; Truong and Foster, 2006). Respondents were asked to rate each attribute of the destination on a 5-point Likert scale. Furthermore, respondents also provided an overall evaluation of their perceived satisfaction with the whole tourism experience in Campania.

\section{Sampling method and data collection}

The survey was conducted in 13 different locations within Campania region by professional interviewers. According to the protocol developed for this study, respondents were selected through a stratified random sampling and interviews were made by face-toface contact method in a sample of hotels during the check out. The main reasoning behind this choice was that, since tourists had just completed their holiday visit, their perception of the facilities, attractions and customer services were still fresh in their minds.

In order to collect information from different tourists' segments, the survey was conducted

Table 1. Demographic characteristics of the sample and number of previous visits

\begin{tabular}{ll}
\hline Gender & $\%$ \\
\hline Male & 53.3 \\
Female & 46.7 \\
\hline & \\
\hline Top 5 countries of residence & $\%$ \\
\hline Italy & 65.1 \\
UK & 9.0 \\
Germany & 6.2 \\
France & 5.2 \\
USA & 3.1 \\
\hline & \\
\hline Number of previous visits & $\%$ \\
\hline First time & 40,2 \\
1 in the past & 23,9 \\
$2-4$ in the past & 20,1 \\
5 or more in the past & 15,8
\end{tabular}

\begin{tabular}{ll}
\hline Age group & $\%$ \\
\hline $15-24$ & 11.3 \\
$25-34$ & 23.3 \\
$35-44$ & 33.1 \\
$45-64$ & 26.2 \\
65 and more & 7.5 \\
\hline
\end{tabular}

\begin{tabular}{ll}
\hline Education level & $\%$ \\
\hline Elementary school & $\mathbf{1 3 . 0}$ \\
Middle school & $\mathbf{2 8 . 6}$ \\
High school & 35.4 \\
University/College & 19.8 \\
Postgraduate & 3.2 \\
\hline
\end{tabular}


in two stages, during the winter season (December) and during the summer season (June/September). At the end of the process, 1.936 questionnaires were collected for data analysis. Compared with the average number of tourist arrivals in the last three years, the sample size corresponded to a standard error of 0.003 with a confidence level of $95 \%$. Demographic characteristics of the sample (Table 1) were highly representative of the different segments of the regional tourism.

\section{Data analysis and results}

Although the application of IPA has always been considered very simple and intuitive, over the years several different approaches to inferring priorities and measuring importance emerged in the literature (Bacon, 2003; Fuchs and Weiermair, 2003). First, as noted by Bacon (2003), in most published IPA studies importance was evaluated through direct ratings (e.g. 7-point scales anchored to "not at all important" and "extremely important"), while other studies estimated importance of services attributes through indirect measures such as standardized / unstandardized regression coefficients or simple correlation coefficients. In this study, indirect measures were used to infer importance scores, based on a correlation analysis were the overall satisfaction was used as the dependent variable and the performance scores on the single items were used as the independent variables. Such approach was consistent with previous research (Lowenstain, 1995) and it seemed more suitable to reflect the importance of attributes and to avoid the important methodological problems discussed in the previous paragraphs.

Second, positioning the vertical and horizontal axes on the grid is matter of judgment (Martilla and James, 1977; Bacon, 2003). In some applications the cross-point was placed in the middle of the scale ("scale-centred approach"),

Table 2. Importance-Performance scores

\begin{tabular}{|c|c|c|c|}
\hline Item & $\begin{array}{l}\text { Average } \\
\text { Score }\end{array}$ & $\begin{array}{l}\text { Standard } \\
\text { Deviation }\end{array}$ & $\begin{array}{l}\text { Corr. } \\
\text { Pearson }\end{array}$ \\
\hline Comfort of accommodation & 3.97 & 0.913 & $0.450^{(\star *)}$ \\
\hline Cleanliness of accommodation & 4.05 & 0.898 & $0.391^{(\star \star)}$ \\
\hline Accommodation personnel friendliness and competence & 4.17 & 0.875 & $0.416^{(*)}$ \\
\hline Quality and variety of restaurants & 3.93 & 0.942 & $0.441^{(\star \star)}$ \\
\hline Typicality of food and restaurants & 3.90 & 0.956 & $0.448^{(\star \star)}$ \\
\hline Quality of public transportation services & 3.21 & 1.032 & $0.387^{(*)}$ \\
\hline Availability of local transportation services & 3.32 & 1.038 & $0.282^{(\star *)}$ \\
\hline Easiness to get around & 3.20 & 1.047 & $0.273^{(* *}$ \\
\hline Quality of tourism information services & 3.35 & 0.879 & $0.399^{(*)}$ \\
\hline Availability of tourism signals & 3.34 & 0.943 & $0.366^{(\star *)}$ \\
\hline Availability of guided tour services & 3.42 & 0.958 & $0.366^{(\star *)}$ \\
\hline Comfort of beaches & 3.38 & 1.047 & $0.232^{(\star \star)}$ \\
\hline Cleanliness of sea & 3.48 & 1.020 & $0.260^{(* *)}$ \\
\hline Availability of health services and facilities & 3.53 & 1.037 & $0.269^{(\star \star)}$ \\
\hline Sustainability of nightlife and entertainment & 3.49 & 0.916 & $0.363^{(* *)}$ \\
\hline Availability of shopping facilities & 3.65 & 0.931 & $0.362^{(\star *)}$ \\
\hline Availability of sport facilities and activities & 3.22 & 1.023 & $0.234^{(\star \star)}$ \\
\hline Historic and artistic heritage maintenance & 3.70 & 0.964 & $0.474^{(*)}$ \\
\hline $\begin{array}{l}\text { Overall quality and organization of the cultural and historical } \\
\text { sites }\end{array}$ & 3.69 & 0.950 & $0.437^{(\star *}$ \\
\hline Availability and quality of events & 3.72 & 0.890 & $0.447^{(\star \star)}$ \\
\hline Feeling of personal safety and security & 3.17 & 1.067 & $0.298^{(\star *)}$ \\
\hline Availability of parking & 2.72 & 1.084 & $0.156^{(* *)}$ \\
\hline Overall cleanliness of the streets and public places & 2.78 & 1.123 & $0.209^{(* *)}$ \\
\hline $\begin{array}{l}\text { Availability of public services and facilities (i.e. toilette, banks, } \\
\text { etc.) }\end{array}$ & 3.23 & 0.958 & $0.105^{(\star *)}$ \\
\hline Overall satisfaction toward the destination & 3.84 & 0.875 & - \\
\hline
\end{tabular}

"'Significant Correlation at 0,01 level 
while in other studies the cross point was located at the centre of data ("data-centred approach") (Bacon, 2003). In this study the cross-point was set at the mean importance and mean performance values. Such approach was coherent with suggestions provided by Martilla and James in their seminal work (1977), arguing that "the value of this approach is in identifying relative than absolute levels of importance and performance".

Descriptive results of the data analysis are reported in Table 2. Perceived performance of the different items were obtained through the average scores of tourists' perceptions, while correlation coefficients between the single environmental factors and the overall perceived satisfaction were used as implicit measures of the related importance. All the items identified had a positive impact on the perceived satisfaction, with significant level of correlation. Results showed that the highest correlations were reported for the quality and organization of the historical attractions, the comfort of the accommodation, the quality of the local food and the availability of events, indicating the importance of these attributes.

The mean scores of the performance statements evidenced a fairly high level of tourists' satisfaction, with values of the single items ranging from 2.72 to 4.17 and an overall satisfaction mean of 3.84 . Tourists gave the top ratings to the following items: "accommodation personal friendliness and competence" $(\mathrm{M}=4.17)$, "cleanliness of the accommodation" $(M=4.05)$, "quality and variety of restaurants" $(\mathrm{M}=3.93)$ and "typicality of food and restaurant" $(\mathrm{M}=3.90)$.

After obtaining the implicitly derived importance and the satisfaction performance of all tourism satisfaction attributes, the 24 items were plotted on the IPA matrix (Figure 3). The average scores of importance and performance were used as reference in the grid.

As shown in Figure 3, the highest number of

\section{IMPORTANCE}

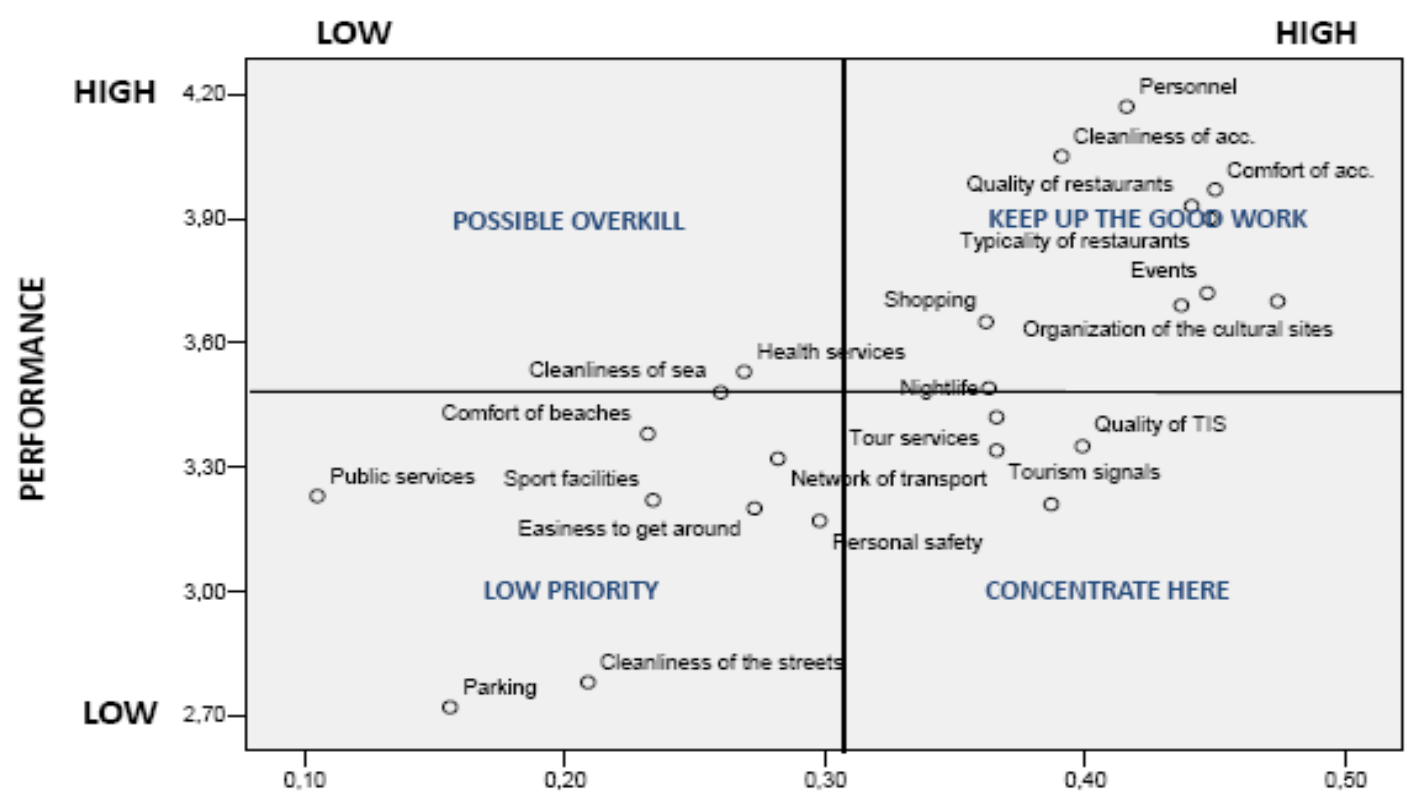

Figure 3. Importance-Performance matrix 
items (9) felt into the Keep up the good work quadrant, including the friendliness and competence of the contact personnel, cleanliness and comfort of the accommodation, the quality and typicality of restaurants, the nightlife opportunities, the quality of events, and the maintenance and organization of cultural sites. On the other hand, the Concentrate here quadrant captured 4 items: quality of tourism information services, availability of guided tours, availability of tourism signals and availability of local transportation. Such elements seem to represent the first area of intervention for the regional policy makers in order to improve the perceived tourist's satisfaction. Eight satisfaction attributes loaded in the Low Priority quadrant, including the quality of sport facilities, the level of public services, the comfort of the beaches, the personal safety, the easiness to get around, the cleanliness of the streets and the availability of parking. They were rated as below average for both importance and performance. This implies that relatively fewer resources should be expended in this area. However it should be noted that some of items - feeling of personal safety, the quality of the local transportation and the easiness to get around - were positioned very close to the Concentrate Here quadrant, suggesting that the regional policy makers should increase their efforts to improve on also these aspects. Finally, only two satisfaction attributes - health services and cleanliness of the sea - were included in the Possible Overkill quadrant.

\section{Conclusion and implications}

Given the increasing competition among national and international tourist destinations, the ability to provide high-quality and satisfactory tourism experiences represent a critical source of competitive advantage. Results from the academic literature on tourism marketing show that a satisfactory tourism experience is able to affect post-visit behavioural intentions, like the intention to return in a destination (Chen and Tsai, 2007) and the willingness to recommend it (Bignè et al., 2001; Chi and Qu, 2008). Recent results have also found that tourist satisfaction is a significant antecedent of intentions to buy products made in the sojourn country, suggesting potential area of collaboration between the tourism sector and the national companies for the promotion of national products (De Nisco et al., 2012). Since tourism has been seen as a driving force of regional development, the availability of management tools aiming to help policy makers and practitioners to develop a more clear understanding of tourists' perceptions of the main strengths and weaknesses of the destination represents an essential input of the destination management process.

This study supports the adoption of the Importance-Performance Analysis (IPA) (Martilla and James, 1977) as a "lowcost/easily managed" tool for evaluating tourist satisfaction. Although this scheme has been widely used in the tourism sector, the present study is one of the few to employ it from a "destination" perspective rather from a "tourism service" perspective. As a consequence, drawing from service marketing and tourism marketing literatures, in this study tourist satisfaction is operationalized through a large and comprehensive set of attributes, including tourism services (i.e. accommodation, food, entertainment), accessibility (i.e. quality of the public transport, easy to move around), physical components (i.e. maintenance of the heritage attractions, tourism signals) and quality of life (i.e. personal safety, public services, street cleanliness). Such components seem able to encompass the different aspects of the tourism destination experience; therefore, they could be used by other destinations for the assessment of tourist satisfaction.

From a managerial prospective, the application of the IPA scheme to the Campania region through a survey conducted on a statistically relevant sample of tourists provides a reliable evidence of the main strengths and weaknesses of the tourism experience offered in the destination. Thus, results can be used as a reference in order to address public and private strategies aiming to improve the perceived satisfaction of the holiday.

In particular, the study identifies as prior area of intervention the improvement of basic tourism services, such as information, transportation, signals and guided tours. Such services - 
which are usually delivered by the public sector - are located in the high importance/low performance grid importance and so they are perceived as relevant determinants of perceived quality of the tourists' experience.

On the other hand, the IPA grid identifies a set of attractiveness elements that can be viewed as the strengths of the destination. Such elements include the most relevant categories of tourism services delivered by the private sector: the accommodation services (room cleanliness and personnel competence and friendliness) and the food services (quality and typicality of restaurants). Arising from the IPA findings, it can be suggested that high valued features of accommodation and food services might be further highlighted as advertising tools both in the marketing strategies promoted by the public sector and in the promotional strategies employed by the local private hospitality industry, or become the object of public/private marketing strategies.

Moreover, the IPA results can be used as a benchmarking tool in order to support the further improvement of the level of service quality. At the same time, the proposed framework could be adopted by other destinations to evaluate the quality of the experience offered to visitors, also comparing their own strengths and weaknesses with other potential competitor destinations. In this sense, the proposed analysis may be useful also as a strategic marketing tool able to show the main elements for differentiating tourist offer.

In the specific case of Campania our results show a high-perceived value of the heritage attractions. The Campania region encloses worldwide renowned UNESCO heritage sites like the archaeological excavations of Pompei and Ercolano, the Royal Palace of Caserta and the historical town centre of Naples. Since such attractions are able to project unique destination characteristics, they can be used as significant positioning elements in the destination marketing process at both national and international levels.

\section{References}

Bacon, D. R. (2003). A Comparison of Approaches to Importance-Performance
Analysis. International Journal of Market Research, 45(1), 55-71.

Bigné, J.E., Sanchez, M.I. \& Sanchez, J. (2001). Tourism image, evaluation variables and after purchase behaviour: inter-relationship. Tourism Management, 22(6), 607-616.

Bitner, M.J. (1992). Servicescapes: The Impact of Physical Surroundings on Customers and Employees. Journal of Marketing, 56 (2), 57-71.

Bowen, D. \& Clarke J. (2002) Reflections on Tourist Satisfaction Research: Past, Present and Future. Journal of Vacation Marketing, 8, 297-308.

Cadotte, E. R., Woodruff, R. B. \& Jenkins, R. L. (1987). Expectations and norms in models of consumer satisfaction. Journal of Marketing Research, 24, 305-314.

Casarin, F. \& Andreani J. C. (2002). La soddisfazione del turista: problemi teorici e operativi. Proceedings of the International Conference "Le Tendenze del Marketing", Ecole Supérieure de Commerce de Paris EAP, January 25-26, 2002.

Chadee, D. \& Mattsson J. (1996). An Empirical Assessment of Customer Satisfaction in Tourism. The Services Industries Journal, 16(3), 305-320.

Chen, C.F. \& Tsai D.C. (2007). How destination image and evaluative factors affect behavioral intentions? Tourism Management 28, 1115-1122.

Chi, C.G-Q. \& Qu, H. (2008). Examining the structural relationships of destination image, tourist satisfaction and destination loyalty: An integrated approach. Tourism Management, 29, 624-636.

Chon, K. (1989). Understanding recreational travellers: motivation, attitude and satisfaction. The Tourist Review, 44, 3-7.

Chu, R.K.S. \& Choi T. (2000). An importanceperformance analysis of hotel selection factors in the Hong Kong hotel industry: a comparison of business and leisure travellers. Tourism Management, 21, 363377.

De Nisco, A., Mainolfi, G. Marino, V. \& Napolitano, M.R. (2012). Tourism experience, country image and post-visit intentions: a study on international tourists in Italy. In Bertoli G., R. Resciniti (eds.) (2012) International Marketing and the 
An Importance-Performance analysis of tourist satisfaction at destination level: evidence from Campania (Italy).

Country of Origin Effect. Cheltenham (UK): Edward Elgar, 65-80.

Del Bosque, I.R. \& San Martin, H. (2008). Tourist Satisfaction: a Cognitive-Affective Model. Annals of Tourism Research, 35, 551-573.

Deng, W. (2007). Using a revised importanceperformance analysis approach: The case of Taiwanese hot spring tourism. Tourism Management, 28, 1274-1284.

Duke, C. R. \& Mount, A. S. (1996). Rediscovering Performance-Importance Analysis of Products. Journal of Product \& Brand Management, 5(2), 43-54.

Duke, C. R. \& Persia M. A. (1996). Performance-Importance Analysis of escorted tour evaluations. Journal of Travel and Tourism Marketing, 5(3), 207223.

Edward, M. \& George, B.P. (2008). Tourism Development in the State of Kerala, India: a study of destination attractiveness. European Journal of Tourism Research, 1(1), 16-38.

Ennew, C., Reed, G. \& Binks, M. R. (1993). Importance-Performance Analysis and the Measurement of Service Quality. European Journal of Marketing, 27(2), 5961.

Francken, D. A. \& van Raaij, W.F. (1981). Satisfaction with leisure time activities. Journal of Leisure Research, 13(4), 337352.

Fuchs, M. \& Weiermair, K. (2003). New Perspectives of Satisfaction Research in Tourism Destinations. Tourism Review, 58(3), 6-14.

Geng-Qing Chi, C. \& Qu, H. (2008). Examining the structural relationships of destination image, tourist satisfaction and destination loyalty: An integrated approach. Tourism Management, 29, 624-636.

Gursoy, D., Chen, J. \& Geng-Qing Chi, C. (2014). Theoretical examination of destination loyalty formation. International Journal of Contemporary Hospitality Management, 26(5), 809-827.

Huang, Y. \& Hsu J. (2006). Using ImportancePerformance Analysis in Evaluating Taiwan Medium and Long Distance National Highway Passenger Transportation Service Quality. Journal of
American Academy of Business, 8(2), 98104.

Hudson, S. \& Shepherd, G. W. H. (1998). Measuring service quality at tourism destinations: An application of importanceperformance analysis to an alpine ski resort. Journal of Travel \& Tourism Marketing, 7(3), 61-77.

Janes, P. \& Wisnom, M. S. (2003). The Use of Importance Performance Analysis in the Hospitality Industry: A Comparison Of Practices. Journal of Quality Assurance in Hospitality \& Tourism, 4 (1/2), 23-45.

Joseph, M., Allbright, D. Stone, G. Sekhon, Y. \& Tinson, J. (2005). ImportancePerformance Analysis of UK and US Bank Customer Perceptions of Service Delivery Technologies. International Journal of Financial Services Management, 1(1), 415.

Kotler, P., Haider, D. H. \& Rein, I. (1993). Marketing Places: attracting investment, industry and tourism to cities, states, and nations. New York: The Free Press.

Kozak, M. (2001). Comparative assessment of tourist satisfaction with destinations across two nationalities. Tourism Management, 22, 391-401.

Martilla, J.A. \& James, J. C. (1977). Importance-Performance Analysis. Journal of Marketing, 41(1), 77-79.

Matzler, K., Sauerwein, E. \& Heischmidt, K. A. (2003). Importance-Performance Analysis Revisited: The Role of the Factor Structure of Customer Satisfaction. Service Industries Journal, 23(2), 112-129.

Middleton, V. T. C. \& Clarke J. (2001). Marketing in travel and tourism (3ed), Oxford: Butterworth-Heinemann.

Oh, H. \& Parks S. C. (1997). Customer satisfaction and service quality: A critical review of the literature and research implications for the hospitality industry. Hospitality Research Journal, 20(3), 3564.

Oliver, R.L. (1980). A cognitive model of the antecedents and consequences of satisfaction decisions. Journal of Marketing Research, 17(4), 46-49.

Oliver, R.L. (1993). Cognitive, affective, and attribute bases of the satisfaction response. Journal of Consumer Research, 20 (3), 418-430. 
Parasuraman, A., Zeithaml, V. A. \& Berry, L. L. (1985). A conceptual model of service quality and its implications for future research. Journal of Marketing, 49 (4), 41 50.

Parasuraman, A., Zeithaml, V. A. \& Berry, L. L. (1988). SERVQUAL: a multiple-item scale for measuring customer perceptions of service quality and its implications for future research. Journal of Retailing, 64 (1), $12-40$.

Pike, S. (2004). The Use of Repertory Grid Analysis and Importance-Performance Analysis to Identify Determinant Attributes of Universities. Journal of Marketing for Higher Education, 14(2), 1-18.

Pizam, A. \& Milman, A. (1993). Predicting satisfaction among first time visitors to a destination by using the expectancydisconfirmation theory. International Journal of Hospitality Management, 12(2), 197-209.

Pizam, A. \& Ellis, T. (1999). Customer satisfaction and its measurement in hospitality enterprises. International Journal of Contemporary Hospitality Management, 11(7), 326-339.

Riviezzo, A., De Nisco, A. \& Napolitano, M. R. (2009). Importance-Performance Analysis as a Tool in Evaluating Town Centre Management Effectiveness. International Journal of Retail \& Distribution Management, 37(9), 748-764.

Ryan, C. (1995). Researching Tourist Satisfaction: Issues, Concepts, Problems. London: Routledge.

Slack, N. (1994). The Importance-Performance Matrix as a Determinant of Improvement Priority. International Journal of Operations \& Production Management, 14(5), 59-75.

Smith, S. \& Costello, C. (2009). Culinary tourism: Satisfaction with a culinary event utilizing importance-performance grid analysis. Journal of Vacation Marketing, 15(2), 99-110.

Söresson, A. \& von Friedrichs, Y. (2013). An importance-performance analysis of sustainable tourism: A comparison between international and national tourists. Journal of Destination Marketing \& Management, 2, 14-21.
Tribe, J. \& Snaith T. (1998). From SERVQUAL to HOLSAT: holiday satisfaction in Varadero, Cuba. Tourism Management, 19(1), 25-34.

Truong, T. \& Foster D. (2006). Using HOLSAT to evaluate tourist satisfaction at destinations: the case of Australian holidaymakers in Vietnam. Tourism Management, 27, 842-855.

Tse, D.K. \& Wilton, P. C. (1988). Models of consumer satisfaction formation: An extension. Journal of Marketing Research, 25, 204-212.

Wade, D.J. \& Eagles, P.F.J. (2003). The Use of Importance-Performance Analysis and Market Segmentation for Tourism Management in Parks and Protected Areas: An Application to Tanzania's National Parks. Journal of Ecotourism, 2(3), 196-212.

Wilkins, H. (2010). Using ImportancePerformance Analysis to Appreciate Satisfaction in Hotels. Journal of Hospitality Marketing \& Management, 19, 866-888.

Yoon, Y. \& Uysal, M. (2005). An examination of the effects of motivation and satisfaction on destination loyalty: A structural model. Tourism Management, 26(1), 45-56.

Yüksel, A. \& Yüksel, F. (2001). The expectancy-disconfirmation paradigm: a critique. Journal of Hospitality \& Tourism Research, 2, 107-131.

Zang, H.Q. \& Chow, I. (2004). Application of importance-performance model in tour guides' performance: evidence from mainland Chinese outbound visitors in Hong Kong. Tourism Management, 25, 8191.

Zeithaml, V.A., Berry, L.L. \& Parasuraman, A. (1985). Problems and strategies in services marketing. Journal of Marketing, 49(2), 33-47.

Zeithaml, V.A., Berry, L.L. \& Parasuraman, A. (1996). The behavioural consequences of service quality. Journal of Marketing, 60(2), 31-46. 